\title{
HUBUNGAN ASUPAN KALSIUM, NATRIUM, KALIUM, DAN KEBIASAAN MEROKOK DENGAN KEPADATAN TULANG PRIA DEWASA AWAL
}

\author{
Gabrielle Nindya Kirana Pradipta, Deny Yudi Fitranti*) \\ Program Studi Ilmu Gizi Fakultas Kedokteran Universitas Diponegoro \\ Jl.Dr.Sutomo No.18, Semarang, Telp (024) 8453708, Email : gizifk@undip.ac.id
}

\begin{abstract}
Background: Osteoporosis in men has not been a concern despite the morbidity due to osteoporosis are higher in men than women. Low bone density in men can be caused by low calcium and potassium intake, high sodium intake, and smoking habits.

Objective: To determine the correlation of calcium, sodium, potassium, and smoking with bone density in young adult men.

Method: Research is an observational study using cross sectional design with 46 men aged 19-24 years oldin the Faculty of Animal and Agricultural Sciences, Diponegoro University. Intake subject collected from FFQ (Food Frequency Questionnaire) semi-quantitative, smoking habits from interviews, bone density was measured using QUS (Qualitative Ultrasound), and physical activity was obtained from recording of the daily activities using the record form of physical activity $2 \times 24$ hours. Bivariate analysis using rank Spearman and multivariate analysis using multiple linier regression.

Result: There are $71,7 \%$ and $89,1 \%$ subjects with low calcium and potassium intake and 60,9\% subjects with high sodium intake. Subjects consumed 2 cigarettes/day. A total of 13,0\% of the subjects had mild activity. The results showed an association of calcium intake $(p=0.006 ; r=0.401)$ and potassium intake $(p=0.000 ; r=0.730)$ with bone density. Multivariate analysis showed 63,7\% of bone density is affected by the intake of calcium, potassium, and physical activity.

Conclusion: Intake of calcium and potassium associated with bone density in young adult men. Sodium intake and smoking habits are not related to bone density in young adult men.

Keyword: bone density, calcium intake, sodium intake, potassium intake, smoking habits, physical activity, young adult men
\end{abstract}

\begin{abstract}
ABSTRAK
Latar Belakang: Osteoporosis pada pria belum menjadi perhatian meskipun angka kesakitan akibat osteoporosis ditemukan lebih tinggi pada pria dibanding wanita. Rendahnya kepadatan tulang pria dikarenakan asupan yang salah seperti kurangnya asupan kalsium dan kalium, tingginya asupan natrium, dan kebiasaan merokok.

Tujuan: Mengetahui hubungan asupan kalsium, natrium, kalium, dan kebiasaan merokok dengan kepadatan tulang pria dewasa awal.

Metode: Penelitian observasional menggunakan desain cross sectional dengan 46 pria usia 19-24 tahun di Jurusan Peternakan Fakultas Peternakan dan Pertanian Universitas Diponegoro. Asupan subjek didapat dari wawancara menggunakan FFQ (Food Frequency Questionnaire) semi kuantitatif, data kebiasaan merokok didapat dari wawancara, kepadatan tulang diukur menggunakan QUS (Qualitative Ultrasound), dan aktivitas fisik diperoleh dari pencatatan kegiatan sehari menggunakan formulir record aktivitas fisik $2 \times 24$ jam. Analisis bivariat menggunakan rank Spearman dan multivariat menggunakan uji regresi linier ganda.

Hasil: Subjek dengan asupan kalsium dan kalium kategori kurang sebanyak 71,7\% dan 89,1\%. Sebanyak 60,9\% memiliki asupan natrium kategori lebih. Rata-rata konsumsi rokok 2 batang/hari. Sebanyak 13,0\% subjek memiliki aktivitas ringan. Hasil uji hubungan menunjukkan adanya hubungan asupan kalsium $(p=0,006 ; r=0,401)$ dan kalium ( $p=0,000 ; r=0,730$ ) dengan kepadatan tulang. Analisis multivariat menunjukkan 63,7\% kepadatan tulang dipengaruhi oleh asupan kalsium, kalium, dan aktivitas fisik.

Kesimpulan: Asupan kalsium dan kalium berhubungan dengan kepadatan tulang pria dewasa awal. Asupan natrium dan kebiasaan merokok tidak berhubungan dengan kepadatan tulang pria dewasa awal.

Kata Kunci: kepadatan tulang, asupan kalsium, asupan natrium, asupan kalium, kebiasaan merokok, aktivitas fisik, pria dewasa awal

\section{PENDAHULUAN}

Osteoporosis adalah kondisi rendahnya kepadatan tulang seseorang sehingga dapat meningkatkan risiko fraktur. ${ }^{1}$ Penelitian di Tangerang pada Tahun 2011 menyebutkan terdapat

6,5\% usia 18-24 tahun yang menderita osteoporosis dan $51,2 \%$ yang terkena osteopenia. ${ }^{2}$ Osteopenia adalah keadaan rendahnya kepadatan tulang yang ditandai dari hasil pengukuran kepadatan tulang dengan nilai $T$-score di antara $-1,0$ hingga $-2,5 .{ }^{1}$
\end{abstract}

\footnotetext{
${ }^{*}$ Penulis Penanggungjawab
} 
Hasil analisa data risiko osteoporosis yang dilakukan oleh Puslitbang Gizi Depkes RI menunjukkan prevalensi osteopenia di Indonesia mencapai $41,2 \%$. $^{3}$ Jika osteopenia tidak ditangani, maka dapat menyebabkan osteoporosis.

Osteoporosis pada pria kurang diperhatikan karena proses osteoklas yang terjadi pada pria di atas 55 tahun tidak secepat pada wanita. ${ }^{4}$ Namun, angka kesakitan akibat osteoporosis ditemukan lebih tinggi pada pria dibanding pada wanita. ${ }^{5}$ Osteoporosis pada pria disebabkan oleh beberapa faktor, meliputi penurunan hormon testosteron seiring bertambahnya usia, genetik, endokrin, dan gaya hidup seperti kurangnya aktivitas fisik, kebiasaan merokok, dan asupan zat gizi yang tidak seimbang. ${ }^{2,6,7}$ Beberapa zat gizi yang mempengaruhi kepadatan tulang adalah kalsium, protein, fosfor, natrium, dan kalium. ${ }^{8,9}$

Pada pria dewasa awal usia 18-24 tahun, terjadi puncak pembentukan kepadatan tulang. ${ }^{10}$ Namun, gaya hidup yang ditunjukkan oleh pria dewasa awal justru dapat mengakibatkan penurunan kepadatan tulang. Pria dewasa awal cenderung kurang mengonsumsi makanan tinggi kalsium dan kalium, tetapi mengonsumsi makanan tinggi natrium. ${ }^{3,11}$ Survei menunjukkan bahwa asupan kalsium rata-rata masyarakat Indonesia per hari hanya mencapai seperempat dari kebutuhan yang dianjurkan. ${ }^{3}$ Asupan kalsium yang kurang dari kebutuhan dapat menyebabkan penurunan kepadatan tulang. Hal ini diperburuk dengan pola makan tinggi natrium rendah kalium yang banyak dijumpai di kelompok dewasa awal. ${ }^{12}$

Tingginya asupan natrium akan mempengaruhi metabolisme kalsium. ${ }^{13}$ Kalsium akan diekskresikan bersama dengan natrium di urin sehingga ketika asupan natrium berlebih, kalsium akan terdesak dan akan diekskresikan melalui urin. Terjadinya peningkatan ekskresi kalsium dapat menyebabkan kepadatan tulang berkurang. ${ }^{7}$ Peningkatan $100 \mathrm{mmol}$ natrium di urin dapat memprediksi adanya peningkatan 1,04 mmol ekskresi kalsium di urin. ${ }^{14}$ Penelitian lain juga menunjukkan bahwa ekskresi natrium di urin $\geq 3,4$ gram/hari menandakan bahwa asupan natrium meningkat dan berefek negatif terhadap kepadatan tulang. ${ }^{15}$

Penelitian telah banyak membuktikan bahwa asupan kalium mampu menurunkan ekskresi kalsium di urin dan menurunkan resorpsi tulang lewat mekanisme keseimbangan asam basa di tubuh. ${ }^{9,16}$ Penelitian menunjukkan bahwa pemberian suplementasi kalium sitrat $60 \mathrm{mEq}$ selama dua tahun, pada orang dewasa yang tidak terkena osteoporosis, mampu meningkatkan kepadatan tulang di tubuh sebesar $1,3 \% .{ }^{17}$ Terdapat pula penelitian lain yang mengatakan terjadinya penurunan ekskresi kalsium di urin dari $200 \pm 14$ $\mathrm{mg} /$ hari menjadi $192 \pm 19 \mathrm{mg} /$ hari pada seseorang yang telah diberi kalium sitrat. ${ }^{18}$ Sumber kalium, yaitu buah-buahan dan sayuran, yang bersifat basa berfungsi mempertahankan $\mathrm{pH}$ homeostasis ketika tubuh dalam kondisi asam. ${ }^{10,19}$ Suasana asam mampu mempercepat proses pembongkaran tulang. ${ }^{19}$

Pola makan yang salah tersebut diperburuk dengan gaya hidup kurang sehat yang dapat mempengaruhi kepadatan tulang, contohnya merokok. Merokok dapat menurunkan absorpsi kalsium dan konsentrasi PTH (Parathyroid Hormone).$^{20}$ Merokok juga dapat meningkatkan radikal bebas dan stress oksidatif yang dapat mempengaruhi resorpsi tulang. ${ }^{21}$ Berdasarkan Riskesdas Tahun 2010, prevalensi perokok kelompok dewasa awal di Indonesia sebanyak $64,7 \% .{ }^{22}$ Apabila dibandingkan, prevalensi perokok lebih banyak ditemukan pada pria yaitu sebesar $38,4 \%$ daripada wanita sebesar $0,9 \% .^{23}$

Tujuan penelitian ini adalah untuk mengetahui hubungan antara asupan kalsium, natrium, kalium, dan kebiasaan merokok dengan kepadatan tulang pada pria dewasa awal. Diharapkan dengan adanya penelitian ini, pola makan salah yang mampu menurunkan kepadatan tulang pada pria dewasa awal dapat dicegah.

\section{METODE PENELITIAN}

Penelitian dilaksanakan di lingkungan Fakultas Peternakan dan Pertanian Universitas Diponegoro pada bulan Juni 2015. Penelitian ini merupakan penelitian observasional dengan desain cross sectional. Populasi terjangkau penelitian adalah seluruh mahasiswa Jurusan Peternakan Fakultas Peternakan dan Pertanian Universitas Diponegoro yang berusia 19-24 tahun dan berjenis kelamin laki-laki. Berdasarkan perhitungan besar sampel menggunakan rumus penelitian analitik korelasi didapatkan subjek minimal penelitian berjumlah 46 orang. Agar menghindari terjadinya drop out maka diberikan penambahan sebesar $10 \%$ sehingga total subjek berjumlah 51 subjek.

Pemilihan subjek dilakukan menggunakan metode consecutive sampling yaitu dengan mengambil subjek yang datang dan memenuhi kriteria inklusi untuk dimasukkan dalam subjek penelitian hingga jumlah subjek minimal terpenuhi. Kriteria inklusi penelitian adalah pria berusia 19-24 tahun; tidak memiliki kebiasaan mengonsumsi alkohol; tidak sedang melakukan diet 
vegetarian $>5$ tahun; memiliki IMT (Indeks Massa Tubuh) $18,5-22,9 \mathrm{~kg} / \mathrm{m}^{2}$; tidak memiliki penyakit diabetes mellitus, gagal ginjal, dan gangguan hormon tiroid; tidak mengonsumsi obat antasid, glukokortikoid, heparin, anticonvulvant, diuretik thiazide, dan statin selama setahun terakhir; serta bersedia menjadi subjek penelitian dengan menandatangani informed consent.

Variabel terikat penelitian adalah kepadatan tulang; variabel bebas berupa asupan kalsium, natrium, kalium, dan kebiasaan merokok; serta variabel perancu berupa aktivitas fisik, asupan protein, fosfor, dan kafein. Kepadatan tulang didefinisikan sebagai nilai yang didapat setelah mengukur kepadatan tulang subjek dengan alat QUS (Qualitative Ultrasound) yang hasilnya dinyatakan dalam bentuk $T$-score dengan nilai antara -1 hingga $-2,5$ SD dikategorikan sebagai osteopenia, sedangkan <-2,5 SD termasuk dalam kategori osteoporosis. QUS merupakan metode yang digunakan untuk skrining awal pada tumit seseorang yang berisiko tinggi terkena osteoporosis.

Asupan kalsium, natrium, kalium, dan fosfor didapat dari rata-rata per hari asupan makanan dan minuman yang dikonsumsi oleh subjek yang diperoleh dari FFQ (Food Frequency Questionnaire) semi kuantitatif kemudian dianalisis menggunakan nutrisurvey dan dibandingkan dengan kebutuhan AKG (Angka Kecukupan Gizi). Hasil ukur asupan kalsium, natrium, kalium, dan fosfor adalah mg/hari. Angka Kecukupan Gizi kalsium sebesar $1100 \mathrm{mg} /$ hari, natrium sebesar $1500 \mathrm{mg} /$ hari, kalium sebesar $4700 \mathrm{mg} /$ hari, dan fosfor sebesar $700 \mathrm{mg} / \mathrm{hari}^{24}$ Asupan kalsium, natrium, kalium, dan fosfor akan dikategorikan cukup bila tingkat asupan berada dalam rentang 80110\%. ${ }^{25}$ Asupan akan dikategorikan kurang jika tingkat asupan $<80 \%$ dan lebih jika tingkat asupan $>110 \%$.

Asupan protein adalah rata-rata per hari asupan protein yang dikonsumsi oleh subjek dalam satuan gram yang diperoleh dari FFQ semi kuantitatif kemudian dianalisis menggunakan nutrisurvey, dan dikonversikan dalam bentuk persen untuk mengetahui persentase pemenuhan kebutuhan protein subjek dalam sehari. Tingkat asupan protein adalah perbandingan antara asupan protein dengan kebutuhan protein sebesar 1,25 $\mathrm{g} / \mathrm{kgBB}$ kemudian dikalikan $100 \% .{ }^{26}$ Asupan protein $<80 \%$ termasuk dalam kategori asupan kurang, 80-110\% termasuk dalam asupan cukup, dan $>110 \%$ termasuk dalam asupan lebih.
Asupan kafein adalah rata-rata per hari asupan kafein yang berasal dari makanan dan minuman yang dikonsumsi subjek dalam satuan mg/hari yang diperoleh dari FFQ semi kuantitatif. Asupan kafein $<300 \mathrm{mg} /$ hari dapat dikategorikan ke dalam asupan normal. Kebiasaan merokok didefinisikan sebagai rata-rata jumlah rokok yang dihisap dalam satuan batang/hari. Data banyaknya batang rokok yang dikonsumsi oleh subjek diperoleh dari hasil wawancara.

Aktivitas fisik didefinisikan sebagai ratarata besarnya energi dalam satuan kkal yang dikeluarkan selama 24 jam, dihitung berdasarkan jenis dan lama kegiatan yang dilakukan dengan cara menaksir pengeluaran energi. Data aktivitas fisik diperoleh melalui pencatatan kegiatan yang dilakukan oleh subjek selama sehari. Proses pencatatan akan dilakukan selama dua hari dengan menggunakan formulir record aktivitas fisik $2 \times 24$ jam. ${ }^{27}$ Kemudian data dari formulir tersebut akan dikonversi menjadi kkal dan dikelompokkan ke dalam kategori aktivitas ringan, sedang, berat, atau sangat berat. Aktivitas fisik termasuk dalam kategori ringan jika energi yang dikeluarkan $<2100$ kkal, kategori sedang jika energi yang dikeluarkan antara 2100-2399 kkal, kategori berat jika energi yang dikeluarkan antara 2400-2699 kkal, dan kategori sangat berat jika energi yang dikeluarkan $\geq 2700 \mathrm{kkal}$.

Analisis data dibedakan menjadi analisis univariat, bivariat, dan multivariat. Analisis univariat dilakukan untuk mendeskripsikan data subjek penelitian. Data akan ditampilkan dalam bentuk rerata, SD (standar deviasi), nilai minimal, dan nilai maksimal, serta dalam distribusi frekuensi. Uji normalitas data menggunakan Saphiro-Wilk. Analisis bivariat menggunakan uji rank Spearman untuk menguji hubungan antara asupan kalsium, natrium, kalium, protein, fosfor, kebiasaan merokok, dan aktivitas fisik dengan kepadatan tulang. Analisis multivariat menggunakan uji regresi linier ganda untuk menguji variabel yang paling berpengaruh terhadap kepadatan tulang.

\section{HASIL PENELITIAN \\ Karakteristik Subjek}

Subjek penelitian ini adalah 46 pria dewasa awal usia 19-24 tahun. Terdapat 5 orang $(10,9 \%)$ subjek yang termasuk dalam kategori osteopenia sedangkan $41(89,1 \%)$ lainnya termasuk dalam kategori normal. 
Tabel 1. Nilai Minimum, Maksimum, Rerata, Standar Deviasi, dan Hasil Uji Hubungan Asupan Kalsium, Asupan Natrium, Asupan Kalium, Tingkat Protein, Asupan Fosfor, Asupan Kafein, Aktivitas Fisik, dan Kepadatan Tulang

\begin{tabular}{lcccccc}
\hline \multicolumn{1}{c}{ Variabel } & $\mathbf{n}$ & Minimum & Maksimum & $\begin{array}{c}\text { Rerata } \pm \\
\text { Standar } \\
\text { Deviasi }\end{array}$ & r & p \\
\hline $\begin{array}{l}\text { Asupan Kalsium } \\
\text { (mg) }\end{array}$ & 46 & 126,30 & 3776,60 & $714,8 \pm 6,00$ & 0,401 & 0,006 \\
$\begin{array}{l}\text { Asupan Natrium (mg) } \\
\text { Asupan Kalium (mg) }\end{array}$ & 46 & 1264,00 & 3405,50 & $1781,2 \pm 3,84$ & $-0,120$ & 0,429 \\
Kebiasaan Merokok & 46 & 689,70 & 10275,00 & $2264,7 \pm 1,60$ & 0,730 & 0,000 \\
(btg/hr) & 0,00 & 20,00 & $2,51 \pm 5,13$ & 0,171 & 0,255 \\
Tingkat Asupan & 46 & 38,73 & 169,76 & $96,87 \pm 3,69$ & $-0,244$ & 0,102 \\
$\begin{array}{l}\text { Protein (\%) } \\
\text { Asupan Fosfor (mg) }\end{array}$ & 46 & 396,20 & 3651,60 & $1124,3 \pm 6,12$ & $-0,192$ & 0,202 \\
Asupan Kafein (mg) & 46 & 9,75 & 660,43 & $137,8 \pm 1,48$ & $-0,258$ & 0,084 \\
Aktivitas Fisik (kkal) & 46 & 1806,00 & 4527,00 & $2782,0 \pm 7,00$ & 0,810 & 0,000 \\
Nilai $t$-score & 46 & $-1,90$ & 2,30 & $0,3 \pm 1,03$ & - & - \\
Kepadatan Tulang & & & & & & \\
(SD) & & & & & & \\
\hline
\end{tabular}

Tabel 2. Tabulasi Silang Kategori Asupan Kalsium, Asupan Natrium, Asupan Kalium, Asupan Protein, Asupan Fosfor, Asupan Kafein, dan Aktivitas Fisik dengan Kepadatan Tulang

\begin{tabular}{|c|c|c|c|c|}
\hline \multirow{2}{*}{ Kategori Variabel } & & \multicolumn{2}{|c|}{ Kategori Kepadatan Tulang } & \multirow{2}{*}{ Total } \\
\hline & & Normal & Osteopenia & \\
\hline \multirow[t]{3}{*}{ Asupan Kalsium } & Kurang & $31(93,9 \%)$ & $2(6,1 \%)$ & $33(71,7 \%)$ \\
\hline & Cukup & $7(87,5 \%)$ & $1(12,5 \%)$ & $8(17,4 \%)$ \\
\hline & Lebih & $3(60,0 \%)$ & $2(40,0 \%)$ & $5(10,9 \%)$ \\
\hline Jumlah & & $41(89,1 \%)$ & $5(10,9 \%)$ & $46(100 \%)$ \\
\hline \multirow[t]{3}{*}{ Asupan Natrium } & Kurang & $0(0 \%)$ & $0(0 \%)$ & $0(0 \%)$ \\
\hline & Cukup & $17(94,4 \%)$ & $1(5,6 \%)$ & $18(39,1 \%)$ \\
\hline & Lebih & $24(85,7 \%)$ & $4(14,3 \%)$ & $28(60,9 \%)$ \\
\hline Jumlah & & $41(89,1 \%)$ & $5(10,9 \%)$ & $46(100 \%)$ \\
\hline \multirow[t]{3}{*}{ Asupan Kalium } & Kurang & $36(87,8 \%)$ & $5(12,2 \%)$ & $41(89,1 \%)$ \\
\hline & Cukup & $4(100 \%)$ & $0(0 \%)$ & $4(8,7 \%)$ \\
\hline & Lebih & $1(100 \%)$ & $0(100 \%)$ & $1(2,2 \%)$ \\
\hline Jumlah & & $41(89,1 \%)$ & $5(10,9 \%)$ & $46(100 \%)$ \\
\hline Tingkat & Kurang & $17(89,5 \%)$ & $2(10,5 \%)$ & $19(41,3 \%)$ \\
\hline \multirow[t]{2}{*}{ Protein } & Cukup & $8(100 \%)$ & $0(0 \%)$ & $8(17,4 \%)$ \\
\hline & Lebih & $16(84,2 \%)$ & $3(15,8 \%)$ & $19(41,3 \%)$ \\
\hline Jumlah & & $41(89,1 \%)$ & $5(10,9 \%)$ & $46(100 \%)$ \\
\hline \multirow[t]{3}{*}{ Asupan Fosfor } & Kurang & $4(80,0 \%)$ & $1(20,0 \%)$ & $5(10,9 \%)$ \\
\hline & Cukup & $11(84,6 \%)$ & $2(15,4 \%)$ & $13(28,3 \%)$ \\
\hline & Lebih & $26(92,9 \%)$ & $2(7,1 \%)$ & $28(60,9 \%)$ \\
\hline Jumlah & & $41(89,1 \%)$ & $5(10,9 \%)$ & $46(100 \%)$ \\
\hline \multirow[t]{2}{*}{ Asupan Kafein } & Normal & $37(92,5 \%)$ & $3(7,5 \%)$ & $40(87,0 \%)$ \\
\hline & Tinggi & $4(66,7 \%)$ & $2(33,3 \%)$ & $6(13,0 \%)$ \\
\hline Jumlah & & $41(89,1 \%)$ & $5(10,9 \%)$ & $46(100 \%)$ \\
\hline \multirow[t]{4}{*}{ Aktivitas Fisik } & Ringan & $1(16,7 \%)$ & $5(83,3 \%)$ & $6(13,0 \%)$ \\
\hline & Sedang & $10(100 \%)$ & $0(0 \%)$ & $10(21,7 \%)$ \\
\hline & Berat & $13(100 \%)$ & $0(0 \%)$ & $13(28,3 \%)$ \\
\hline & Sangat Berat & $17(100 \%)$ & $0(0 \%)$ & $17(37,0 \%)$ \\
\hline Jumlah & & $41(89,1 \%)$ & $5(10,9 \%)$ & $46(100 \%)$ \\
\hline
\end{tabular}

Tabel 1 menunjukkan rerata asupan kalsium subjek sebesar $714,8 \mathrm{mg} /$ hari dan rerata asupan kalium sebesar 2264,7 $\mathrm{mg} / \mathrm{hari}$ dikategorikan kurang dari AKG (Angka Kecukupan Gizi). Berbeda dengan asupan kalsium dan kalium, asupan natrium justru melebihi AKG. Rerata asupan natrium adalah $1781,2 \mathrm{mg} /$ hari. Rerata aktivitas fisik subjek adalah $2782 \mathrm{kkal}$ dan termasuk dalam aktivitas sangat berat. 
Analisis hubungan antara variabel asupan, kebiasaan merokok, aktivitas fisik, dan kepadatan tulang menggunakan uji rank Spearman. Pada tabel 1 terlihat bahwa asupan kalsium dan kalium memiliki hubungan dengan kepadatan tulang dengan $\mathrm{p}<0,05$. Nilai korelasi asupan kalsium dan kalium masing-masing 0,401 dan 0,730 serta berkorelasi positif yang berarti semakin tinggi asupan kalsium dan kalium maka semakin tinggi nilai kepadatan tulang. Berbeda dengan asupan kalsium dan kalium, asupan natrium dan kebiasaan merokok tidak berhubungan dengan kepadatan tulang dengan $p>0,05$. Asupan natrium berkorelasi negatif yang berarti semakin tinggi asupan natrium maka nilai kepadatan tulang akan semakin turun. Aktivitas fisik sebagai variabel perancu terbukti berhubungan dengan kepadatan tulang dengan $\mathrm{p}<$ 0,05 dan $r=0,801$ serta berkorelasi positif yang menandakan semakin berat aktivitas fisik yang dilakukan maka dapat meningkatkan kepadatan tulang.

Pada Tabel 2, terdapat 33 orang subjek (71,7\%) yang kurang mengonsumsi kalsium dan 2 orang subjek $(6,1 \%)$ di antaranya termasuk dalam kategori osteopenia. Sebanyak 4 orang subjek $(14,3 \%)$ dengan asupan natrium lebih termasuk dalam kategori osteopenia. Terdapat 5 orang subjek $(12,2 \%)$ dengan asupan kalium kurang dari kebutuhan termasuk dalam kategori osteopenia. Tiga orang subjek $(15,8 \%)$ memiliki asupan protein lebih dari kebutuhan termasuk dalam kategori osteopenia. Sebanyak 2 orang subjek $(7,1 \%)$ memiliki asupan fosfor melebihi kebutuhan termasuk dalam kategori osteopenia. Dua orang subjek $(33,3 \%)$ mengonsumsi kafein melebihi anjuran konsumsi kafein per hari termasuk kategori osteopenia. Ditemukan adanya 5 subjek $(83,3 \%)$ dengan aktivitas fisik ringan dan termasuk dalam kategori osteopenia.

Variabel dengan $\mathrm{p}<0,25$ akan dimasukkan ke dalam uji multivariat guna melihat variabel yang paling mempengaruhi kepadatan tulang. Variabel-variabel tersebut antara lain asupan kalsium, kalium, protein, fosfor, kafein, dan aktivitas fisik. Hasil uji multivariat akan dinyatakan dalam Tabel 3.

Tabel 3. Hasil Uji Multivariat Asupan Kalsium, Asupan Kalium, Asupan Fosfor, Asupan Kafein, dan Aktivitas Fisik

\begin{tabular}{lcc}
\hline Variabel & Koefisien & Adjusted $R$ Square \\
\hline Asupan Kalsium & 0,0001 & 0,637 \\
Asupan Kalium & 0,0001 & \\
Aktivitas Fisik & 0,001 & \\
Konstanta & $-2,684$ & \\
\hline
\end{tabular}

* regresi linier ganda

Berdasarkan Tabel 3 diketahui bahwa asupan kalsium dan kalium sebagai variabel bebas serta aktivitas fisik sebagai variabel perancu yang paling mempengaruhi kepadatan tulang dengan $\mathrm{p}<$ 0,05 dan adjusted $R$ square sebesar 0,637 yang berarti $63,7 \%$ variasi kepadatan tulang dipengaruhi oleh asupan kalsium, kalium, dan aktivitas fisik. Persamaan garis yang didapat dari hasil uji multivariat adalah $\mathrm{y}=-2,684+0,0001$ (asupan kalsium) $+0,0001$ (asupan kalium) $+0,001$ (aktivitas fisik). Koefisien regresi 0,0001 menyatakan bahwa setiap penambahan asupan kalsium sebesar $1 \mathrm{mg}$, kepadatan tulang akan bertambah sebesar 0,0001. Koefisien regresi 0,0001 menyatakan bahwa setiap penambahan asupan kalium sebesar $1 \mathrm{mg}$, kepadatan tulang akan bertambah sebesar 0,0001. Koefisien regresi 0,001 menyatakan bahwa setiap penambahan aktivitas fisik sebesar 1 kkal, kepadatan tulang akan bertambah sebesar 0,001 .

\section{PEMBAHASAN}

Hasil penelitian menunjukkan $71,7 \%$ pria dewasa awal kurang mengonsumsi kalsium dengan $6,1 \%$ tergolong dalam kelompok osteopenia. Uji korelasi menggunakan rank Spearman membuktikan adanya hubungan bersifat positif antara asupan kalsium dengan kepadatan tulang. Hal ini sesuai dengan salah satu penelitian kohort prospektif yang juga hubungan positif antara asupan kalsium dengan kepadatan tulang. ${ }^{28}$ Sebuah penelitian cross sectional yang melibatkan 2309 pria pun menyebutkan bahwa asupan kalsium berpengaruh terhadap kepadatan tulang belakang. ${ }^{5}$ Asupan kalsium merupakan salah satu faktor yang mempengaruhi kepadatan tulang dan dapat mempertahankan kepadatan tulang dalam waktu jangka panjang. ${ }^{6}$ Ketika proses pembentukan tulang mulai terjadi, garam kalsium akan membentuk kristal yang disebut hidroksiapatit. Kristal tersebut akan bertambah padat selama proses pembentukan tulang berlangsung. ${ }^{29}$

Sebanyak $89,1 \%$ pria dewasa awal kurang mengonsumsi kalium dan $12,2 \%$ di antaranya 
terkena osteopenia. Setelah dilakukan uji korelasi, terbukti adanya hubungan positif antara asupan kalium dan kepadatan tulang. Hubungan antara asupan kalium dan kepadatan tulang terjadi lewat mekanisme keseimbangan asam basa. ${ }^{19}$ Rendahnya asupan buah dan sayur sebagai sumber kalium dapat meningkatkan produksi asam harian yang dapat memicu terjadinya pembongkaran tulang. Penelitian secara acak yang melibatkan 201 orang dewasa membuktikan bahwa pemberian suplementasi kalium sitrat sebesar $60 \mathrm{mEq}$ selama dua tahun mampu meningkatkan kepadatan tulang. ${ }^{17}$

Hasil penelitian menunjukkan $60,9 \%$ pria dewasa awal mengonsumsi natrium lebih dari AKG (Angka Kecukupan Gizi). Sebanyak 14,3\% pria dewasa awal dengan asupan natrium melebihi AKG ternyata memiliki kepadatan tulang yang rendah atau osteopenia. Namun, hasil uji korelasi menunjukkan tidak adanya hubungan antara asupan natrium dengan kepadatan tulang. Tingginya asupan natrium memang dapat mempengaruhi metabolisme kalsium dengan cara meningkatkan ekskresi kalsium dalam urin. ${ }^{30}$ Lebih dari $99 \%$ natrium dan $95 \%$ kalsium direabsorpsi di ginjal. ${ }^{13}$ Sebanyak 60-70\% kalsium direabsorpsi di tubulus proksimal secara pasif. Proses reabsorpsi tersebut terjadi bersamaan dengan absorpsi natrium. Oleh karena itu, apabila terjadi peningkatan tekanan arterial akibat asupan natrium berlebih, dapat menyebabkan penurunan reabsorpsi natrium dan kalsium di bagian proksimal sehingga dapat menyebabkan peningkatan ekskresi kalsium dalam urin atau hiperkalsiuria. ${ }^{35}$ Hiperkalsiuria yang terjadi akibat asupan natrium berlebih biasanya terjadi pada kelompok dewasa lanjut atau wanita post-menopause. ${ }^{13}$

Hasil uji hubungan menunjukkan tidak adanya hubungan antara kebiasaan merokok dengan kepadatan tulang. Terdapat beberapa faktor terkait gaya hidup perokok yang mampu menurunkan kepadatan tulang yaitu konsumsi minuman beralkohol melebihi anjuran, konsumsi makanan dengan gizi yang tidak seimbang, serta kurang melakukan aktivitas fisik. ${ }^{32,33}$ Penelitian yang menunjukkan adanya hubungan antara kebiasaan merokok dengan kepadatan tulang biasanya terjadi pada wanita post menopause atau pria dewasa lanjut yang telah terkena paparan rokok dalam waktu yang lama. ${ }^{34}$

Tidak adanya hubungan antara asupan natrium dan kebiasaan merokok dengan kepadatan tulang dapat dikaitkan dengan hormon reproduksi. Pada pria dewasa awal belum terjadi penurunan fungsi hormon. Salah satu hormon yang berperan dalam mekanisme pembentukan kepadatan tulang adalah hormon testosteron. Hormon testosteron mampu meningkatkan kepadatan tulang. ${ }^{35}$ Peningkatan kepadatan tulang diperkirakan akibat fungsi anabolik protein umum testosteron dan pengendapan garam-garam kalsium yang menghasilkan peningkatan kepadatan tulang. Rendahnya kadar serum testosteron dapat mempercepat penurunan kepadatan dan meningkatkan risiko osteoporosis. Pada suatu penelitian eksperimental, injeksi testosteron terbukti mampu mempercepat proses osteoblas. ${ }^{36}$

Sebanyak $13,0 \%$ pria dewasa awal memiliki aktivitas fisik ringan dan $83,3 \%$ di antaranya terkena osteopenia. Hasil uji hubungan menunjukan adanya hubungan positif antara aktivitas fisik dengan kepadatan tulang. Jaringan tulang selalu terbentuk dan biasanya terbentuk akibat adanya stimulus dari aktivitas fisik. ${ }^{37}$ Selama melakukan aktivitas fisik, tekanan mekanik akan diberikan pada tulang dan dapat menimbulkan adanya kontraksi otot yang berefek pada peningkatan kepadatan tulang. Sebuah penelitian membandingkan antara dampak aktivitas berjalan, berlari, menaiki tangga; dengan olahraga angkat beban dan mendayung. Hasil penelitian menunjukkan bahwa aktivitas berjalan, berlari, dan menaiki tangga lebih cepat meningkatkan kepatan tulang dibandingkan olahraga angkat beban dan mendayung. ${ }^{38}$

Hasil penelitian menunjukkan bahwa asupan kalsium, kalium, dan aktivitas fisik merupakan variabel yang paling mempengaruhi kepadatan tulang. Sebanyak $63,7 \%$ kepadatan tulang dapat diakibatkan oleh asupan kalsium, kalium, dan aktivitas fisik. Sedangkan 36,3\% kepadatan tulang diakibatkan oleh variabel lain yang tidak diteliti.

\section{SIMPULAN}

Hasil uji hubungan menunjukkan asupan kalsium, kalium, dan aktivitas fisik memiliki hubungan positif dengan kepadatan tulang pria dewasa awal. Berbeda dengan asupan kalsium, kalium, dan aktivitas fisik; asupan natrium dan kebiasaan merokok tidak memiliki hubungan dengan kepadatan tulang pria dewasa awal. Uji multivariat menunjukkan sebanyak $63,7 \%$ variasi kepadatan tulang pria dewasa awal dipengaruhi oleh asupan kalsium, kalium, dan aktivitas fisik.

\section{SARAN}

Bagi pria dewasa awal, perlu memperhatikan kecukupan asupan kalsium, natrium, dan kalium serta sebaiknya pria dewasa 
awal, dan meningkatkan aktivitas fisik agar tidak terjadi penurunan kepadatan tulang.

\section{DAFTAR PUSTAKA}

1. Nelms, M., Sucher, K. P., Lacey, K. \& Roth, S. L. Nutrition Therapy \& Pathophysiology; 2010: Hal. 777-786.

2. Permatasari, T. A. E. Hubungan Asupan Kalsium dan Faktor Risiko Lainnya dengan Kejadian Osteoporosis pada Kelompok Dewasa Awal di Wilayah Ciputat-Tangerang Selatan. 2011; Hal. 178.

3. Keputusan Menteri Kesehatan Republik Indonesia Nomor 1142/MENKES/SK/XII/2008 tentang Pedoman Pengendalian Osteoporosis.

4. Yulianingsih Syam, Djarot Noersasongko, Haryanto Sunaryo. Fraktur Akibat Osteoporosis. Jurnal e-Clinic (eCl). 2014; 2: Hal. 1-7.

5. Gennari L., Bilezikian JP. Osteoporosis in Men. Endocrinol Metab Clin North Am. 2007; 36(2): Hal. 399-419.

6. Zhu, K. \& Prince, R. L. Calcium and bone. Clinical Biochemistry. 2012; 45: Hal. 936-942.

7. Murad, R., Qadir, M., Khalil, R. \& Baig, M. Association Of Urinary Calcium And Phosphate With Bone Mineral Density Among Postmenopausal Women. Biomedica. 2012; 28: Hal. 78-81.

8. Sedó, K., Medeiros, M. De, Lúcia, V. \& Araújo, L. High bone density and bone health. Endocrinol Nutr. 2012; 59: Hal. 207-214.

9. Palacios, C. The role of nutrients in bone health, from $\mathrm{A}$ to $\mathrm{Z}$. Critical reviews in food science and nutrition: 2006; 46: Hal. 621-628.

10. Thompson, J., Manore, M. \& Vaughan, L. The Science of Nutrition. Pearson: USA. 2011: Hal. 409-444.

11. Saufika, A., Retnaningsih \& Alfiasari Gaya hidup dan kebiasaan makan mahasiswa. Jurnal Ilmu Keluarga dan Konsumen. 2012; 5: Hal. 157-165.

12. Lanham-New, S. A. The Balance of Bone Health: Tipping the Scales in Favor of Potassium-Rich, Bicarbonate-Rich Foods. The Journal of Nurition. 2008: Hal. 172-177.

13. Teucher, B. \& Fairweather-Tait, S. Dietary sodium as a risk factor for osteoporosis: where is the evidence? Proceedings of the Nutrition Society. 2003; 62: Hal. 859-866.

14. Blackwood, A. M., Sagnella, G. A., Cook, D. G. \& Cappuccio, F. P. Urinary calcium excretion, sodium intake and blood pressure in a multi-ethnic population: results of the Wandsworth Heart and Stroke Study. Journal of Human Hypertension. 2001; 15: Hal. 229-237.

15. Laura D. C., Karen D. B., Andrew J. B., M. David B., Jean A. M., Kathleen A. P. et al. Effects of a low sodium diet on bone metabolism. J Bone Miner Metab. 2005; 23: Hal. 506-513.

16. Feng J. H., Maciej M., Christine C., Nirmala D. M., Vidya A., William D. F. et al. Effects of Potassium
Chloride and Potassium Bicarbonate on Endothelial Function, Cardiovascular Risk Factors, and Bone Turnover in Mild Hypertensives. Hypertension. 2010: Hal. 681-688.

17. Jehle, S., Hulter, H. N. \& Krapf, R. Effect of Potassium Citrate on Bone Density, Microarchitecture, and Fracture Risk in Healthy Older Adults without Osteoporosis: A Randomized Controlled Trial. J Clin Endocrinol Metab. 2014; 98: Hal. 207-217.

18. Sellmeyer, D. E., Schloetter, M. \& S, D. E. D. E. Potassium Citrate Prevents Increased Urine Calcium Excretion and Bone Resorption Induced by a High Sodium Chloride Diet. The Journal of Clinical Endocrinology \& Metabolism. 2015; 87: Hal. 2008-2012.

19. Weaver, C. M. Potassium and Health. American Society for Nutrition. 2013; 4: Hal. 3685-3775.

20. Lie, S. A., Meyer, H. E., Øyen, J., Gjesdal, C. G. \& Nyga, O. K. Smoking and Body Fat Mass in Relation to Bone Mineral Density and Hip Fracture: The Hordaland Health Study. PLOS ONE. 2014; 9: Hal. 1-9.

21. Shahab, L. \& Mcewen, A. Smoking and bone health. National Centre for Smoking Cessation and Training. 2012: Hal. 1-6.

22. Isfandari, S. \& Lolong, D. B. Analisa Faktor Risiko dan Status Kesehatan Remaja Indonesia pada Dekade Mendatang. Bul. Penelit. Kesehat. 2014; 42: Hal. 122-130.

23. Nugroho, L. A. Perilaku Merokok pada Anak Jalanan di Kota Semarang. 2014: Hal. 1-13.

24. Angka Kecukupan Gizi (AKG) 2013: Hal 1-3.

25. Gibson. S Rosalind. Principles of Nutrition Assesment second edition. 2005. United States of America: Oxford University Press.

26. Heaney, Robert P., Layman, Donald K., Amount and type of protein influences bone health. The American Journal of Clinical Nutrition. 2008; 87 : Hal. 1567-1570S.

27. G. Kartasapoetra dan H. Marsetyo. Ilmu Gizi (Korelasi Gizi, Kesehatan dan Produktivitas Kerja). Jakarta: Rineka Cipta. 2008: Hal 40-41.

28. Jeri W. N., Kathryn M., Meredith C., Jennifer L. K., Laura K. B., Gail G. et al. Nutritional factors that influence change in bone density and stress fracture risk among young female cross-country runners. The American Academy of Physical Medicine and Rehabilitation. 2010; 2: Hal. 740-750.

29. Rolfes, S. R., Pinna, K. Whitney, E. Understanding Normal and Clinical Nutrition. Yolanda Cossio: Belmont. 2009: Hal 431-439.

30. Birgit T., Jack R. D., Caroline A. S., Gosia M. N., David J. B. Jurian A. H. et al. Sodium and bone health: Impact of moderately high and low salt intakes on calcium metabolism in postmenopausal women. Journal of Bone and Mineral Research. 2008; 23(9): Hal. 1477-1485.

31. Lynda A.Frassetto, R. Curtis Morris, Jr., Deborah E. Sellmeyer, Anthony Sebastian. Adverse Effects 
of Sodium Chloride on Bone in the Aging Human Population Resulting from Habitual Consumption of Typical American Diets. The Journal of Nutrition. 2008: Hal. 1-4.

32. Michele Abate, Daniele Vanni, Andrea Pantalone, Vincenzo Salini. Cigarette smoking and musculoskeletal disorders. Muscles, Ligaments and Tendons Journal. 2013; 3(2): Hal. 63-69.

33. Monica Sneve, Nina Emaus, Ragnar Martin Joakimsen, Rolf Jorde. The association between serum parathyroid hormone and bone mineral density, and the impact of smoking: the Tromso Study. European Journal of Endocrinology. 2008; 158: Hal. 401-409.

34. A. Supervia, X. Nogues, A. Enjuanes, J. Vila, L. Mellibovsky, S. Serano et al. Effect of smoking and smoking cessation on bone mass, bone remodeling, vitamin D, PTH, and sex hormones. J Musculoskelet Neuronal Interact. 2006; 6(3): Hal. 234-241

35. Arthur C.G., John. E.H. Buku Ajar Fisiologi Kedokteran. 1996. Jakarta: Penerbit Buku Kedokteran EGC. Hal. 1247-1258.

36. Michael F., Alexander B., Elena G., Michael H., Darius A.P. Low Testosterone-An Important Predictor of Low Mineral Bone Density in Young Men-Our Own Experience and a Review of Literature. Advance in Sexual Medicine. 2013; 3: Hal. 19-33.

37. Pawel Szulc, Mary L Bouxsein. Overview of osteoporosis: Epidemiology and clinical management. International Osteoporosis Foundation Vertebral Fracture Initiative. 2011: Hal. $1-66$.

38. Linda et al. Physical exercise and osteoporosis: effects of different types of exercises on bone and physical function of postmenopausal women. Arq Bras Endocrinol Metab. 2014; 58 (5): Hal. 514-522. 